\title{
CD209 wt Allele
}

National Cancer Institute

\section{Source}

National Cancer Institute. CD209 wt Allele. NCI Thesaurus. Code C51114.

Human CD209 wild-type allele is located within 19p13 and is approximately 8 kb in length.

This allele, which encodes CD209 antigen immunoprotein, plays a role in T-cell receptor engagement and adaptive immune responses. 